\title{
Pengetahuan dan Perilaku Konsumsi Remaja Putri yang Berhubungan dengan Status Anemia
}

\author{
KNOWLEDGE AND CONSUMPTION BEHAVIOR OF YOUNG WOMEN RELATED \\ TO ANEMIA STATUS
}

\author{
Sintha Fransiske Simanungkalit ${ }^{1 *}$, dan Oster Suriani Simarmata ${ }^{2}$ \\ ${ }^{1}$ Universitas Pembangunan Nasional "Veteran" Jakarta, \\ Jl. RS. Fatmawati No.7 Jakarta Selatan, Pondok Labuh, Depok, Jabar 12450 \\ ${ }^{2}$ Puslitbang Upaya Kesehatan Masyarakat, Balitbangkes, Kemenkes \\ J1. Percetakan Negara No.29 Jakarta Pusat 10560 \\ *Email:sintha_fs@yahoo.com
}

Submitted: 26-02-2019, Revised:30-05-2019, Revised : 20-06-2019, Accepted:02-07-2019

\begin{abstract}
Anemia is a condition where the number of red blood cells or the concentration of oxygen transport in the blood $(\mathrm{Hb})$ is insufficient for the physiology needs of the body. ${ }^{1}$ The prevalence of anemia (15-24 years old) in Indonesia (2018) was 32\%. ${ }^{2}$ The aimed of this study was to determine the relationship between knowledge, tablet knowledge of iron supplementation, nutritional status, Fe intake and consumption patterns of inhibitor and enhancers factors with anemia in adolescent girls. This study found that $63.4 \%$ of girls had anemia. The factors associated with anemia in this study were knowledge ( $p$ value $=0.004$ ), nutritional status ( $p$ value $=0.034$ ) and consumption patterns of Fe inhibitors ( $p$ value $=0.009)$. Based on multivariate test, knowledge of anaemia was obtained as the dominant factor in anemia among adolescent girls with OR 3,3. Suggestions in this study were the need to be counseling about anemia and Fe inhibitor consumption patterns and monitoring nutritional status at UKS SMA/K so that adolescent girls can avoid anemia.
\end{abstract}

Keywords: anemia, knowledge, nutritional status and inhibitor Fe.

\begin{abstract}
Abstrak
Anemia merupakan suatu kondisi dimana jumlah sel darah merah atau konsentrasi pengangkut oksigen dalam darah $(\mathrm{Hb})$ tidak mencukupi untuk kebutuhan fisiologi tubuh. ${ }^{1}$ Prevalensi anemia pada rentang usia 15-24 tahun berdasarkan Riskesdas tahun 2018 adalah 32\%. ${ }^{2}$ Tujuan penelitian ini adalah mengetahui hubungan pengetahuan dan perilaku konsumsi dengan anemia remaja putri. Penelitian ini didapatkan sebanyak $63,4 \%$ remaja putri mengalami anemia. Faktor-faktor yang berhubungan dengan anemia remaja putri dalam penelitian ini adalah pengetahuan $(p$ value $=0,004)$, status gizi $(p$ value $=0,034)$ dan pola konsumsi inhibitor $\mathrm{Fe}(p$ value $=0,009)$. Setelah dilakukan uji multivariat didapatkan pengetahuan anemia sebagai faktor dominan anemia remaja putri dengan OR 3,3. Saran dalam penelitian ini adalah perlunya diberikan penyuluhan mengenai anemia dan pola konsumsi inhibitor Fe serta pemantauan status gizi di UKS SMA/K sehingga para remaja putri terhindar dari anemia.
\end{abstract}

Kata kunci: Anemia, Pengetahuan, Status Gizi, Inhibitor Fe

\section{PENDAHULUAN}

Anemia yaitu jumlah sel darah merah atau konsentrasi pengangkut oksigen dalam darah $\mathrm{Hb}$ tidak mencukupi untuk kebutuhan fisiologi tubuh. ${ }^{1}$ Anemia pada wanita usia subur merupakan tantangan di bidang gizi kesehatan reproduksi. ${ }^{3}$
Anemia saling terkait dengan Target Gizi Global seperti: stunting, wasting dan berat badan lahir rendah. Anemia masuk dalam program Sustained Development Goals (SDG) ke-2 dan ke-3 untuk mengurangi semua bentuk kekurangan gizi dan memastikan kehidupan yang sehat untuk semua usia tahun $2030 .^{4}$ 
Pada wanita usia subur (15-49 tahun) dikategorikan anemia jika memiliki $\mathrm{Hb}<12$ g/ dl. Berdasarkan data Riskesdas 2013 proporsi anemia pada perempuan $(23,9 \%)$ lebih tinggi dibandingkan pada laki-laki $(18,4 \%)$. Proporsi anemia pada kelompok umur 15-24 tahun sebesar 18,4\% tahun $2013 .{ }^{1}$ Berdasarkan data Riskesdas 2018 proporsi anemia pada perempuan $(27,2 \%)$ lebih tinggi dibandingkan pada laki-laki (20,3\%). Proporsi anemia pada kelompok umur 15-24 tahun sebesar 32\% tahun $2018 .{ }^{2}$ Penelitian di India juga didapatkan bahwa remaja putri merupakan kelompok rentan mengalami anemia. ${ }^{5}$ Remaja putri rentan terkena anemia karena mengalami masa menstruasi dan mengejar masa tumbuh. Remaja putri yang sedang menstruasi mengalami kehilangan besi dua kali lipat dibandingkan remaja putra. Selain itu, remaja putri biasanya sangat memperhatikan bentuk badan, sehingga banyak yang membatasi konsumsi makan seperti pada diet vegetarian. ${ }^{6}$ Sehingga untuk mencegah kejadian anemia defisiensi besi, maka remaja puteri perlu dibekali dengan pengetahuan tentang anemia defisiensi besi itu sendiri. ${ }^{7}$ Pencegahan dan pengobatan anemia pada wanita usia reproduksi sangat penting untuk mencegah berat badan lahir rendah, kematian perinatal dan risiko penyakit terkait peran wanita sebaagai ibu. ${ }^{4}$ Program UKS (Usaha Kesehatan Sekolah) di beberapa sekolah belum ada program penanggulangan anemia defisiensi besi bagi remaja putri. Sekolah memberikan peranan penting untuk menanggulangi dan mencegah masalah anemia.

\section{BAHAN DAN METODE}

Penelitian ini menggunakan desain penelitian potong lintang. Penelitian dilakukan di SMA Muhammadiyah 4 Depok dan SMK AlHidayah Cinere pada bulan September - Oktober 2018. Populasi dalam penelitian ini adalah seluruh siswi kelas X dan XI pada kedua sekolah. Untuk menghitung besar sampel dalam penelitian ini digunakan rumus.

$$
\mathrm{n}=\frac{\left\{z_{1-z / 2} \sqrt{2 \overline{\mathrm{P}}(1-\overline{\mathrm{P}})}+z_{1-\beta} \sqrt{\mathrm{P}_{1}\left(1-\mathrm{P}_{1}\right)+\mathrm{P}_{2}\left(1-\mathrm{P}_{2}\right)}\right\}^{2}}{\left(\mathrm{P}_{1}-\mathrm{P}_{2}\right)^{2}}
$$

Besar sampel dalam penelitian ini sebanyak 172 siswi dengan metode acak stratifikasi (stratified random sampling). Metode sampling ini dilakukan karena setiap kelas X dan XI di SMA Muhammadiyah 4 Depok dan SMK Al-Hidayah Cinere dibagi lagi atas beberapa kategori kelas dan banyaknya siswi dalam satu kelas berbeda-beda. Kategori kelas berdasarkan prestasi siswi. Kriteria inklusi dalam penelitian ini adalah siswi kelas X dan XI berusia 15-18 tahun yang dinyatakan aktif oleh pihak sekolah dan setuju mengikuti penelitian ini (dengan menandatangani informed consent). Siswi yang aktif adalah siswi yang terdaftar dan mengikuti proses pembelajaran di sekolah.

Penelitian ini telah mendapatkan persetujuan etik yang diterbitkan oleh Komite Etik Penelitian Kesehatan UPNVJ dengan nomor: B/1600/IX/2018/KEPK. Data yang diperoleh dengan teknik wawancara berdasarkan pertanyaan dalam kuesioner. Adapun data yang dikumpulkan yaitu status gizi menurut umur (IMT/U) berdasarkan pengukuran yang dilakukan saat penelitian berlangsung, pengetahuan anemia dan TTD, Asupan Fe, Frekuensi Konsumsi Inhibitor dan Enhancer Fe. Berat badan didapatkan dengan penimbangan berat badan menggunakan timbangan injak sedangkan tinggi badan dengan menggunakan microtoise. Asupan $\mathrm{Fe}$ dan pola asupan makanan menggunakan FFQ semiquantitative. Status anemia diperoleh Quick Check Hemoglobin dengan pengambilan darah perifer.

Data yang dianalisis hanya data yang lengkap. Analisis data dalam penelitian ini untuk melihat faktor dominan yang menimbulkan anemia pada remaja putri dengan menggunakan regresi logistic berganda.

\section{HASIL}

Berdasarkan hasil penelitian dapat diketahui bahwa siswi SMA/K Depok, yang berusia 12-16 tahun atau dalam kategori remaja awal sebanyak 142 siswi (82,6\%) dan yang berusia 17-25 tahun atau dalam kategori remaja akhir sebanyak 30 siswi (17,4\%).

Status gizi pada penelitian ini berdasarkan IMT/U. Kategori status gizi normal jika berada $\geq-2$ SD s/d 2 SD, sedangkan tidak normal $\leq-2$ SD atau $>2$ SD. Hasil penelitian diketahui bahwa 
siswi SMA/K Depok, yang berada dalam status gizi tidak normal sebanyak 76 siswi $(44,2 \%)$ dan yang berada dalam status gizi normal sebanyak 96 siswi $(55,8 \%)$.

Siswi yang memiliki pengetahuan TTD yang kurang sebanyak 150 siswi (87,2\%) sedangkan siswi yang pengetahuan baik sebanyak 22 siswi (12,8\%).

Berdasarkan hasil penelitian ditemukan $63 \%$ siswi yang anemia. Sebanyak 120 siswi (69,8\%) dengan asupan $\mathrm{Fe}$ yang kurang, sedangkan responden yang memiliki asupan Fe baik sebanyak 52 siswi (30,2\%). Menurut AKG 2013, asupan Fe kurang jika asupan Fe kurang dari 19mg (usia 13-15 tahun ) dan kurang dari 15mg (usia 16-18 tahun). Data asupan Fe diambil berdasarkan wawancara dengan menggunakan tabel semi kuantitatif FFQ (Food Frequency Quetionare).

Sebanyak 86 siswi (50\%) dengan pengetahuan mengenai TTD (Tablet Tambah Darah) kurang, sedangkan responden yang memiliki pengetahuan TTD (Tablet Tambah Darah) baik sebanyak 86 siswi (50\%).

Frekuensi konsumsi inhibitor dan enhancer Fe didapatkan dengan wawancara dengan menanyakan tabel semi kuantitatif FFQ (Food Frequency Quetionare). Sebanyak 88 siswi $(51,2 \%)$ sering mengonsumsi inhibitor $\mathrm{Fe}$, sedangkan 84 siswi (48,8\%) jarang mengonsumsi inhibitor Fe. Sebanyak 94 siswi (54,7\%) jarang mengonsumsi enhancer Fe, sedangkan 78 siswi $(45,3 \%)$ sering mengonsumsi inhibitor Fe.

Berdasarkan Tabel 2 di atas didapatkan ada hubungan pengetahuan anemia dengan anemia remaja putri (pvalue 0,004$)$. Namun dilihat berdasarkan pengetahuan TTD tidak ada hubungan pengetahuan TTD dengan anemia remaja putri (pvalue 0,225). Sementara berdasarkan hubungan status gizi dengan anemia remaja putri (pvalue $0,034)$.

Jika dilihat berdasarkan asupan $\mathrm{Fe}$ tidak ada hubungan asupan Fe dengan anemia remaja putri (pvalue 0,222). Pada penelitian ini ditanyakan konsumsi sumber Fe yang dikonsumsi oleh siswi seperti kacang-kacangan, daging, telur, sayuran hijau. Berdasarkan tabel didapatkan ada hubungan inhibitor Fe dengan anemia remaja putri (pvalue 0,009). Pada penelitian, peneliti melihat konsumsi inhibitor Fe yang ditanyakan adalah seberapa sering konsumsi teh dan kopi. Berdasarkan tabel didapatkan tidak ada hubungan enhancer Fe dengan anemia remaja putri (pvalue 0,511). Bahan makanan yang ditanyakan untuk enhancer adalaha buah yang tinggi kandungan vitamin $\mathrm{C}$ seperti jeruk dan tomat.

Berdasarkan uji chi square, dipilih variable yang memenuhi $\mathrm{p}<0,25$ untuk diuji lanjut dengan regresi logistik berganda. Adapun variabel itu adalah pengetahuan anemia, pengetahuan TTD, status gizi, asupan Fe (besi), frekuensi konsumsi inhibitor Fe dan enhancer Fe.

Tabel 1. Frekuensi Karakteristik Responden

\begin{tabular}{|c|c|c|}
\hline Variabel & Frekuensi (n) & Persentase $(\%)$ \\
\hline Remaja Awal (15-16 thn) & 142 & 82,6 \\
\hline Remaja Akhir (17-18 thn) & 30 & 17,4 \\
\hline \multicolumn{3}{|l|}{ Status Gizi (IMT/U) } \\
\hline Normal (-2 SD s/d 2 SD) & 76 & 44,2 \\
\hline Tidak Normal $(<2$ SD $\&>2$ SD) & 96 & 55,8 \\
\hline \multicolumn{3}{|l|}{ Pengetahuan Tablet Tambah Darah } \\
\hline Kurang $(\leq 60 \%)$ & 150 & 87,2 \\
\hline Baik $(>60 \%)$ & 22 & 12,8 \\
\hline \multicolumn{3}{|l|}{ Pengetahuan Anemia } \\
\hline Kurang $(\leq 60 \%)$ & 86 & 50 \\
\hline Baik $(>60 \%)$ & 86 & 50 \\
\hline \multicolumn{3}{|l|}{ Anemia } \\
\hline Normal (11-12gr/dl) & 63 & 36,6 \\
\hline
\end{tabular}


Anemia $(<11 \mathrm{gr} / \mathrm{dl})$

Asupan Fe

Kurang $<(20 \mathrm{mg} / \mathrm{hr})$

Baik ( $\geq 20 \mathrm{mg} / \mathrm{hr}$ )

Frekuensi Konsumsi Inhibitor Fe

Sering

Frekuensi Konsumsi Enhancer Fe

Tabel 2. Distribusi Kategori Hb Remaja Putri menurut Karakteristik

\begin{tabular}{|c|c|c|c|c|c|c|c|}
\hline \multirow{3}{*}{ Karakteristik } & \multicolumn{4}{|c|}{ Kategori Hb } & \multirow{2}{*}{\multicolumn{2}{|c|}{ Total }} & \multirow{3}{*}{ p-Value } \\
\hline & \multicolumn{2}{|c|}{ Anemia } & \multicolumn{2}{|c|}{ Tidak Anemia } & & & \\
\hline & $\mathbf{N}$ & $\%$ & n & $\%$ & $\mathbf{n}$ & $\%$ & \\
\hline \multicolumn{8}{|l|}{ Pengetahuan Anemia } \\
\hline Kurang & 41 & $47.7 \%$ & 45 & $52.3 \%$ & 86 & $100 \%$ & .004 \\
\hline Baik & 22 & $25.6 \%$ & 64 & $74.4 \%$ & 86 & $100 \%$ & \\
\hline \multicolumn{8}{|l|}{ Pengetahuan TTD } \\
\hline Kurang & 58 & $38.7 \%$ & 92 & $61.3 \%$ & 150 & $100 \%$ & .225 \\
\hline Baik & 5 & $22.7 \%$ & 17 & $77.3 \%$ & 22 & $100 \%$ & \\
\hline \multicolumn{8}{|l|}{ Status Gizi (IMT/U) } \\
\hline Tidak Normal & 28 & $29,2 \%$ & 68 & $70.8 \%$ & 96 & $100 \%$ & .034 \\
\hline Normal & 35 & $46,1 \%$ & 41 & $53,9 \%$ & 76 & $100 \%$ & \\
\hline \multicolumn{8}{|l|}{ Asupan Fe } \\
\hline Kurang & 48 & $40 \%$ & 92 & $60 \%$ & 120 & $100 \%$ & .222 \\
\hline Cukup & 15 & $28,8 \%$ & 37 & $71,2 \%$ & 52 & $100 \%$ & \\
\hline \multicolumn{8}{|c|}{ Frekuensi Konsumsi Inhibitor Fe } \\
\hline Sering & 41 & $46,6 \%$ & 47 & $53,4 \%$ & 88 & $100 \%$ & .009 \\
\hline Jarang & 22 & $26,2 \%$ & 62 & $73.8 \%$ & 84 & $100 \%$ & \\
\hline \multicolumn{8}{|c|}{ Frekuensi Konsumsi Enhancer Fe } \\
\hline Jarang & 37 & $39,4 \%$ & 57 & $60,6 \%$ & 94 & $100 \%$ & .511 \\
\hline Sering & 26 & $33,3 \%$ & 52 & $66,7 \%$ & 78 & $100 \%$ & \\
\hline
\end{tabular}

Tabel 3. Model Akhir Multivariat

\begin{tabular}{|c|c|c|c|c|}
\hline \multirow{2}{*}{ Variabel Independen } & \multirow{2}{*}{ p-Value } & \multirow{2}{*}{ OR } & \multicolumn{2}{|c|}{$95 \%$ CI } \\
\hline & & & Lower & Upper \\
\hline Pengetahuan Anemia & 0,001 & 3,300 & 1,641 & 6,636 \\
\hline Status Gizi (IMT/U) & 0,038 & 2,048 & 1,040 & 4,035 \\
\hline $\begin{array}{l}\text { Frekuensi Konsumsi } \\
\text { Inhibitor Fe }\end{array}$ & 0,009 & 2,506 & 1,261 & 4,981 \\
\hline
\end{tabular}




\section{PEMBAHASAN}

Pada penelitian di SMA Muhammadiyah 4 Depok dan SMKAl-Hidayah Cinere didapatkan proporsi anemia sebesar 63,4\%. Penelitian di Universitas Airlangga pada mahasiswi putri didapatkan bahwa sebanyak 70\% mengalami anemia. ${ }^{8}$ Besarnya proporsi dalam penelitian ini tergolong dalam severe public health problem. ${ }^{9}$ Tingginya prevalensi anemia pada remaja putri mengindikasikan bahwa dibutuhkan pencegahan berupa pemberian pengetahuan dan konsumsi suplementasi besi dan asam folat. Pengetahuan mengenai makanan yang tinggi akan zat besi juga masih rendah. Anemia remaja putri perlu ditangani agar remaja putri mempunyai simpanan zat besi di dalam tubuhnya sebagai persiapan mereka sebelum menikah dan hamil. ${ }^{10}$

Berdasarkan pengetahuan anemia yang kurang didapatkan ada hubungan dengan anemia remaja putri. Penelitian tahun 2012 di SMA Kabupaten Selayar didapatkan ada hubungan pengetahuan dengan anemia remaja putri dengan p-value $0,000 .{ }^{11}$ Hasil penelitian ini sama dengan penelitian di SMK Sukuharjo bahwa ada hubungan pengetahuan anemia dengan anemia remaja putri. $^{12}$ Pengetahuan merupakan hasil dari tahu, dan terjadi setelah orang melakukan penginderaan terhadap suatu obyek tertentu. Pengetahuan atau kognitif merupakan domain yang sangat penting untuk terbentuknya tindakan seseorang. ${ }^{13}$

Berdasarkan Tabel 2 didapatkan tidak ada hubungan pengetahuan TTD dengan anemia remaja putri. Hasil penelitian di SMAN 13 Kota Tangerang juga mendapatkan tidak ada hubungan hubungan pengetahuan TTD dengan anemia remaja putri. ${ }^{14}$ Berdasarkan Peraturan Menteri Kesehatan Republik Indonesi no.88 tahun 2014, tablet tambah darah adalah tablet yang diberikan kepada wanita usia subur dan ibu hamil. Wanita usia subur diberikan 1x seminggu dan 1x sehari selama haid. Pemerintah memberikan spesifikasi tablet tambah darah, yaitu: mengandung zat besi setara dengan $60 \mathrm{mg}$ besi elemental dan asam folat $0,4 \mathrm{mg}$. ${ }^{15}$
Berdasarkan Tabel 2 didapatkan ada hubungan status gizi (IMT/U) dengan anemia remaja putri. Hasil penelitian ini sama dengan penelitian di MTsN Bengkulu dan SMAN 13 Kota Tangerang bahwa ada hubungan status gizi dengan anemia pada remaja putri. ${ }^{14,16}$ Berbeda dengan hasil penelitian di pesantren Darul Ulum Peterongan Jombang didapatkan tidak ada hubungan status gizi dengan anemia remaja putri. ${ }^{17}$

Berdasarkan Tabel 2 didapatkan tidak ada hubungan asupan Fe dengan anemia remaja putri. Hasil penelitian ini sejalan dengan penelitian di Universitas Airlangga tidak ada hubungan asupan Fe dengan anemia remaja putri. ${ }^{8}$ Berbeda dengan hasil penelitian Dwi tahun 2011 didapatkan ada hubungan asupan Fe dengan anemia remaja putri dengan p-value 0,001. ${ }^{18}$ Seorang remaja putri kehilangan zat besi (Fe) sebanyak 12,5-15mg per bulan atau $0,4-0,5 \mathrm{mg}$ zat besi (Fe) per hari selama menstruasi. Sehingga dalam masa growth spurt resiko defisiensi zat besi $(\mathrm{Fe})$ pada remaja putri lebih berisiko dibandingkan remaja putra. ${ }^{9}$

Pemenuhan kebutuhan zat besi ditentukan tingkat penyerapan $\mathrm{Fe}$ dalam tubuh. Tingkat penyerapan zat besi khususnya kategori non heme dipengaruhi inhibitor (penghambat) dan enhancer (mempercepat). ${ }^{19}$ Asupan zat inhibitor dapat menyebabkan anemia terutama zat polifenol yang terdapat dalam kopi dan teh. Pada penelitian ini peneliti melihat frekuensi konsumsi inhibitor (khususnya teh dan kopi) yang dikonsumsi siswi. Berdasarkan Tabel 2 didapatkan ada hubungan inhibitor Fe dengan anemia remaja putri. Hasil penelitian ini sejalan dengan penelitian di Pare-Pare bahwa ada hubungan pola makan khususnya konsumsi teh dengan anemia remaja putri. ${ }^{20}$ Penelitian di Bengkulu juga didapatkan ada hubugan pola konsumsi inhibitor Fe dengan anemia remaja putri. ${ }^{16}$ Konsumsi teh pada satu jam sesudah makan dan dapat menurunkan absorpsi zat besi hingga $85 \%$, hal ini disebabkan karena adanya polyphenol seperti tannin. ${ }^{21}$ Konsumsi secangkir teh bersamaan dengan makanan dapat menurunkan $60 \%$ absorbsi besi. ${ }^{22}$ 
Asupan enhancer Fe berdasarkan tabel didapatkan tidak ada hubungan dengan anemia remaja putri. Hasil penelitian di Makasar demikian juga di Madrasah Aliyah Al-Aziziyah didapatkan tidak ada hubungan enhancer Fe dengan anemia remaja putri. ${ }^{23,24}$ Berbeda dengan hasil penelitian di asrama putri Universitas Airlangga didapatkan ada hubungan enhancer dengan anemia remaja putri $(\mathrm{p}=0,046){ }^{8}$

Berdasarkan Tabel 3 model multivariat didapatkan bahwa pengetahuan anemia merupakan faktor dominan terhadap anemia remaja putri. Remaja putri yang memiliki pengetahuan yang kurang mengenai anemia berisiko 3,3 kali dibandingkan yang pengetahuan baik. Penelitian di MTsN 02 Kota Bengkulu mendapatkan hasil yang berbeda yaitu status gizi merupakan faktor dominan kejadian anemia remaja putri setelah dikontrol kebiasaan sarapan pagi, asupan protein dan pola konsumsi makanan inhibitro penyerapan zat besi. ${ }^{16}$

Sebuah penelitian di India juga didapatkan bahwa perlu pemberian edukasi tentang anemia dan konsumsi jenis makanan yang kaya besi untuk menurunkan angka kejadian anemia remaja putri. ${ }^{5}$ Penelitian di Amerika Latin dan Caribbean didapatkan bahwa remaja putri yang tinggal di daerah perkotaan mempunyai kebiasaan konsumsi makanan tinggi kalori namun miskin akan zat gizi seperti junk food dan fast food. Remaja putri seperti ini rentan mengalami defisiensi zat gizi, akses yang terbatas untuk pelayanan kesehatan/ gizi atau jarang terpapar atau mendapatkan edukasi/penyuluhan gizi khususnya mengenai anemia. Pengetahuan anemia yang kurang akan mempengaruhi pemilihan makanan yang bersifat membantu dan menghambat penyerapan besi dalam tubuh. Semakin sering mengonsumsi makanan yang menghambat (inhibitor)Fe maka akan mempengaruhi status besi dalam tubuh seseorang. Status besi dalam tubuh yang cukup pada saat awal masa remaja dapat mengurangi kecepatan pertumbuhan remaja, karena defisiensi besi dapat mengurangi selera makan, asupan makan dan energi. ${ }^{25}$

\section{KESIMPULAN}

Berdasarkan penelitian ini pengetahuan anemia merupakan faktor utama anemia pada remaja putri. Sehingga, perlu adanya upaya peningkatan pengetahuan pada remaja putri melalui penyuluhan mengenai pengetahuan anemia dan pola konsumsi inhibitor Fe secara berkala yang dapat dilakukan di SMA/SMK.

\section{UCAPAN TERIMA KASIH}

Penulis mengucapkan terima kasih kepada Lembaga Penelitian dan Pengabdian Masyarakat (LPPM) UPN Veteran Jakarta dalam membimbing, memberi masukan dan membiayai penelitian ini. Penulis berterima kasih kepada pihak SMA Muhammadiyah 4 dan SMK AlHidayah Cinere dalam memberikan izin dan kerjasama saat dilakukan penelitian ini. Penulis juga berterima kasih kepada pihak-pihak yang membantu penelitian ini dan mohon maaf untuk tidak dapat mencantumkan nama satu per satu.

\section{DAFTAR RUJUKAN}

1. Balitbangkes RI. Laporan Hasil Riset Kesehatan Dasar Tahun 2013. Jakarta: Balitbangkes, 2013.

2. Balitbangkes RI. Laporan Hasil Riset Kesehatan Dasar Tahun 2018. Jakarta: Balitbangkes, 2018.

3. Kemenkes RI. 2016. Jurnal Kesehatan Reproduksi.

4. WHO. 2016. Strategies to prevent anaemia: Recommendations From An Expert Group Consultation.http://www.searo.who.int/ entity/nutrition/recommendations_on anaemia1.pdf?ua $=1$ diakses tanggal 22 Oktober 2018.

5. Sirvastava Anurag, dkk. 2016. Nutritional anaemiainadolescentgirls:an epidemiological study. https://www.ijcmph.com/index.php/ ijcmph/article/download/801/686 diakses 22 okteober 2018.

6. Sediaoetama, A.D. Ilmu Gizi Untuk 
Mahasiswa Dan Profesi Jilid Ii. Jakarta: Dian Rakyat: 2006.

7. Dharmadi, M. Dkk. Penyuluhan Anemia Defisiensi Besi (Adb) Pada Remaja Puteri Di Sekolah Menengah Atas Negeri 1 Bangli. 03 Oktober 2011. Dharmadi, M. Dkk. (2011).

8. Akib, Afishar dkk., 2017. Kebiasaan Makan Remaja Putri yang Berhubungan dengan Anemia : Kajian Positive Deviance. https://ejournal.unair.ac.id/AMNT/article/ view/6232 diakses 28 november 2018.

9. WHO. 2011. Prevention Of Deficiency Anaemia In Adolescents Role Of Weekly Iron And Folic Acid Supplementation Iron. http:// apps.searo.who.int/PDS_DOCS/B4770. pdf?ua $=1$ diakses 22 Oktober 2018.

10. Srinivas Vani \& Ranjit Mankeshwar 2015. Prevalence and determinants of nutritional anemia in an urban area among unmarried adolescent girls: A community-based cross-sectional study. http://www.ijmedph. org/sites/default/files/IntJMedPublicHealth_2015_5_4_283_165950.pdf diakses tanggl 15 januari.

11. Tenri. 2012. Hubungan Pengetahuan Anemia Dan Tablet Tambah Darah Dengan Kejadian Anemia Pada Remaja Putri Smp. Diakses Tanggal 13 Maret 2018 Pkl 15:09 Wib.

12. Mutalazimah Nur Ainum Hasyim, dkk. 2018. Pengetahuan Risiko, Perilaku Pencegahan Anemia dan Kadar Hemoglobin pada Remaja Putri.https://ejournal.stikespku.ac.id/index. $\mathrm{php} / \mathrm{mpp} /$ article / download /28/183 diakses tanggal 28 Nov 2018.

13. Notoatmodjo. Pengertian Pengetahuan. Rineka Cipta. Jakarta: Rineka Cipta:2003.

14. Siti Rochmah. 2013. Hubungan Pengetahuan Anemia Dan Tablet Tambah Darah Dengan Kejadian Anemia Pada Remaja Putri Sma Negeri. Diakses Tanggal 13 Maret 2018.

15. PMK RI No. 88 Tahun 2014 http://sinforeg. litbang.depkes.go.id/upload/regulasi/PMK No._88_ttg_Tablet_Tambah_Darah_.pdf diakses tanggal 5 Desember 2018.

16. Jaelani Mahmud, dkk. 2017. Faktor Risiko yang Berhubungan dengan Kejadian Anemia pada Remaja Putri https://ejurnal. poltekkes-tjk.ac.id/index.php/JK/article/ download/625/585 diakses tanggal 9 Januari 2019.

17. Sya'Bani Is Rinieng \& Sri Sumarmi, 2016. Hubungan Status Gizi Dengan Kejadian Anemia Pada Santriwati Di Pondok Pesantren Darul Ulum Peterongan Jombang. http:// journal.um-surabaya.ac.id/index.php/JKM/ article/view/503 diakses tanggal 28 nov 2018.

18. Dwi, Kristanti Rahmawati, 2011. Analisis Faktor Penyebab Kejadian Anemia Gizi Besi Pada Remaja Putri Di Sman 2 Kota Bandar Lampung Tahun 2011.

19. Mascitelli. L, Goldstein. MR. Inhibitor of Iron Absorption by Polyphenols as an Anti Cancer Mechanism 2010. Available from https://doi. org/10.1093/qjmed/hcq239.

20. Ayu Dwi Putri Rusman, 2018. Pola Makan Dan Kejadian Anemia Pada Mahasiswi Yang Tinggal Di Kos-Kosan. Jurnal Ilmiah Manusia dan Kesehatan. Mei 2018;1(2).

21. Bhargava, A. et al., 2001. Dietary Intakes and Socioeconomic Factors are Associated with The Hemoglobin Concentration of Bangladesh Women. Am J Clin Nutr, vol 131, p:758-764.

22. Sumarlan, Eka S, dkk. 2018. Iron Status, Prevalence and Risk Factors of Iron Deficiency Anemia Among 12-to 15-YearOld Adolescent Girls from Different Socioeconomic Status in Indonesia http:// journal.ui.ac.id/index.php/health/article/ view/8078 diakses 22 Oktober 2018 .

23. Lilis Indahswari. 2017. Hubungan Pola Konsumsi dengan Kejadian Anemia pada Wanita Prakonsepsi di Kecamatan Ujung Tanah dan Kecamatan Biringkanaya Kota Makassar. http://repository. unhas. ac.id/bitstream/handle/123456789/8092/ Jurna $1 \% 20$ Penelitian \% 20 Lilis \% 20 Indahswari\%20MKMI\%20-\%20Copy.pdf.

24. Herta Masthalina dkk, 2015. Pola Konsumsi (Faktor Inhibitor Dan Enhancer Fe) Terhadap 
Status Anemia Remaja Putri. https://journal. unnes.ac.id/nju/index.php/kemas/article/ view/3516 diakses tanggal 28 November 2018.

25. Chaparro Camila M. \& Chessa K. Lutter. 2010.
Anemia among adolescent and young adult women in Latin America and the Caribbean: A cause for concern. http://www.paho.org/ hq/dmdocuments/2010/AnemiaEngWEB.pdf diakses tanggal 15 januari 2019. 